\title{
Cairo University Fibrosis Index (CUFI): A MicroRNA Based Score for Accurate Prediction of Hepatic Fibrosis: A Biopsy Controlled Study
}

Hanan Abdel-Haleem Abdel-Haleem

Cairo University

Abdel Rahman Zekri Zekri

National Cancer Institute

Mostafa Abdel Moniem Moniem

Theodor Bilharz Research Institute

Ahmed Al Ray Al Ray

Theodor Bilharz Research Institute

Mona Omar Omar

Damietta University

Mohamed Omarn Omran ( $\nabla$ drmmomran@science.helwan.edu.eg )

Helwan University

Dalia Omran Omran

Cairo University

\section{Research Article}

Keywords:

Posted Date: February 7th, 2022

DOI: https://doi.org/10.21203/rs.3.rs-1298036/v1

License: (9) This work is licensed under a Creative Commons Attribution 4.0 International License.

Read Full License 


\section{Abstract}

Background: The exact identification of liver fibrosis is mandatory for customizing therapy and controlling complications. The aim of the current study is to measure the ability to circulate miRNAs; in the diagnosis of hepatic fibrosis.

Methods: Routine laboratory, liver biopsy, and histopathological investigations were done on seventy HCV patients. In addition, estimation of HCV-RNA, serum micro RNA (miRNA)-122, 221, 192, 224, 375, and 885 were done by PCR. To assess the ability of each miRNA, the area under the receiver operating characteristics (AUC) curves were plotted. Significant miRNA were analyzed by linear regression analysis in a stepwise pattern to develop a score for pointing out significant fibrosis. Moreover, the following scores were calculated: aspartate aminotransferase (AST)/alanine aminotransferase (ALT) ratio (AAR), aspartate to platelet ratio index (APRI), FIB-4 score, Hui index, Fibrosis Index (FI), Fibro-Q, Fibro-Alfa Biotechnology Research Center (BRC) score, and Gotebörg University Cirrhosis Index (GUCl).

Results: Patients with significant and advanced fibrosis have significantly lower miR-122. MiR-122, FIB4, total bilirubin, and miR-855 proved to be independent predictors of significant fibrosis in univariate analysis. A novel score; Cairo University Fibrosis Index (CUFI) based on microRNA 122, FIB4, bilirubin, and microRNA 855 were formulated for the identification of significant liver fibrosis. The AUC of the score, for predicting significant and advanced hepatic fibrosis was 0.85 and 0.81 . This AUC was higher than those of other common fibrosis scores.

Conclusion: Cairo University Fibrosis Index proved to be better than other existing scores in assessing fibrosis in chronic hepatitis $\mathrm{C}(\mathrm{CHC})$ patients.

\section{Introduction}

Liver fibrosis induced by Hepatitis $\mathrm{C}$ virus (HCV) is a dynamic, wound healing, process that results from ongoing damage to the hepatocytes from direct viral cytopathic effect or due to immunological response with subsequent activation of hepatic stellate cell and changes in extracellular matrix formation and degradation, including deposition of collagen [1]. In the era of treatment of chronic HCV using highly efficient direct-acting antivirals (DAAs), hepatic fibrosis staging as a triage for therapy indication is no longer as crucial as once believed [2-6]. Rather, precise identification of advanced hepatic fibrosis as well as cirrhosis is highly required for adjusting HCV therapy, tracking possible regression of liver fibrosis after achieving sustained virological response, and proper prevention and treatment of HCV-related end-stage liver disease complications [7-10]. Histopathology is the traditional benchmark for the determination of liver fibrosis stage, but needle liver biopsy procedure is invasive and has some limitations including cost, risk of complications, sampling errors, inaccurate representation of unevenly distributed liver disease as the sample of the liver biopsy parallels a fraction of 1/50,000th of the whole liver [5]. Noninvasive methods for hepatic fibrosis staging in chronic HCV patients including physical (imaging techniques) and biological (serum biomarkers) have become increasingly available over the last few decades [7,8,10-14]. 
Mi-RNA are small non-coding RNAs with an average length of 22 nucleotides that control the translation and transcription of many genes [15]. Mi-RNAs are crucial for the regulation of inflammatory diseases and are considered predictive biomarkers for liver diseases [16, 17]. Scarce studies explored the potential role of circulating miRNAs in the prediction of liver fibrosis stage. The present study was conducted to estimate the accuracy of microRNAs; $122,224,192,375,221$, and 855 in predicting the severity of liver fibrosis. Moreover, we tried to formulate a score and validate it against other noninvasive fibrosis biomarkers; AST/ALT ratio (AAR), FIB-4 score, APRI, Fibrosis Index (Fi), Hui index, Fibro-Alfa, Fibro-Q, Biotechnology Research Center (BRC) score, and GUCl using liver biopsy as the gold standard.

\section{Material And Methods}

\section{Study population}

In this cohort study, 70 consecutive patients suffering chronic hepatitis $\mathrm{C}$ joined from Theodor Bilhariz research institute. Adult patients( $18-70$ years) with virological proof of chronic HCV infection by HCV antibodies and real-time polymerase chain reaction (RT-PCR) were included. Exclusion criteria included other causes of liver disease e.g.a1 anti-Trypsin deficiency, Wilson disease, hemochromatosis, coinfection, with hepatitis B virus (HBV), and non-alcoholic fatty liver disease.

\section{Laboratory assessments}

Laboratory investigations included full blood count, liver biochemical profile was done. HCV-RNA using reverse transcriptase-polymerase chain reaction (RT-PCR) (The Abbott RealTime HCV assay) with detection limit $<10 \mathrm{IU} / \mathrm{ml}$ was done. All testing was performed at a single reference laboratory.

\section{miRNA extraction}

Serum miRNA 122,192, 885, 375, 224, and 221 were evaluated by PCR (Sera had been stored at $-80^{\circ} \mathrm{C}$ till use and RNA separated using TriHReagentLS (Sigma-Aldrich, St. Louis, MO), chloroform, and the mirVanaTM RNA isolation kit (Ambion-ABI, Austin, TX). Total RNA was eluted in $100 \mu \mathrm{l}$ and stored at -20C. Five $\mu$ l of RNA reverse transcribed with the TaqMan miRNA reverse transcription kit and the TaqMan miRNA assay-specific RT primers for miRNAs 122,192,885,375,224 and 221 according to the instructions of the manufacturer (ABI). Real-time PCR was done with three $\mathrm{mL}$ of each CDNA on a Step One TM Plus Real-Time PCR System (ABI) in duplicates. Fractional threshold cycles (CT) expressed the initial concentration of the target sequence. Relative mRNA quantification was calculated using the arithmetic formula $2-\Delta C T$, where $\Delta C T$ is the difference between the $C T$ of a given target $C D N A$ and an endogenous reference $c D N A$. Thus, this value yielded the amount of the target normalized to an endogenous reference.

\section{Liver biopsy}

Liver biopsy was performed under ultrasound guidance using a disposable automatic Guillotine tru-cut needle (16-gauge). The acceptable sample was at least $10 \mathrm{~mm}$ in length and contained at least 5 portal 
tracts. The fibrosis stage was determined according to the METAVIR group scoring system [18]. The present study was organized in accordance with the Declaration of Helsinki 1973 and Good Clinical Practice guidelines. The Ethics Committee of Endemic Medicine and the Hepato-gastroenterology Department reviewed and approved the protocol. Every patient signed informed consent before taking part in the study.

\section{Statistical analysis}

Results were examined utilizing SPSS software package version 25.0 (SPSS Inc., Chicago, IL). Numerical data were demonstrated as mean $\pm S D$ and differences were carried out using analysis of variance (ANOVA) or Student's t-test. Tests were significant when the P-value $<0.05$. Patients were classified into 2 groups; significant liver fibrosis (F2-F4) and advanced liver fibrosis (F3-F4). Noninvasive hepatic fibrosis indexes were calculated; table 1. To assess the ability of each biomarkerfor differentiating between the two groups, the AUC curves were plotted; significant biomarkers were selected and analyzed by linear regression analysis in a stepwise pattern to develop a score that combined the independent factors for pointing out significant fibrosis. The best cutoff value of the predictive score was optimized for identifying significant fibrosis. On the other hand, the diagnostic performances of our developed score were compared with other common noninvasive liver fibrosis scores. $p<0.05$ is considered significant. $P$ value $<0.01$ is considered highly significant, $p<0.001$ is considered very significant and $p<0.0001$ is considered extremely significant.

\section{Results}

The study cohort included 70 chronic HCV patients [mean age $40.9 \pm 8.5$ years, $70 \%$ men $(n=49)$ ]. According to liver histopathology, F0, F1, F2, F3, F4 were identified in 7, 37, 14, and 11, patients respectively. Patients were classified into significant liver fibrosis $(\mathrm{no}=26)$ and advanced liver fibrosis (no =11). Baseline demographic and laboratory values and mi-RNAs levels are shown in table 2 and figure $1(A-B)$. The mean $\pm S D, A U C$ of the predictive score, and common noninvasive liver fibrosis scores were summarized in table 3. For prediction of significant liver fibrosis., the AUC of common liver fibrosis scores; FIB 4, GUCl, Fibro-Q, APRI, BRC, AAR, Hui index, Fibro- Alfa and FI were 0.67, 0.62, 0.62, 0.62, 0.61, $0.60,0.54,0,53$ and 0.46 ; respectively

\section{Performance characteristics of biomarkers using areas under the ROC curves}

Univariate analysis of all comparing biomarkers in the present study identified micro RNA 122, Fib4, bilirubin, and micro RNA 855 as independent markers for discriminating significant liver fibrosis. The AUC were $0.79,0.67,0.66$ and 0.64 , respectively (Table 4). The previous analysis indicated that micro RNA 122 was the most efficient index among other biomarkers.

\section{Diagnostic performances of the score}


The multivariate discriminant analysis (MDA) identified the best formula which included microRNA 122, FIB4, microRNA 855, and bilirubin as a novel score that was able to predict significant liver fibrosis noninvasively.

\section{Cairo University Fibrosis Index $($ CUFI) $=4.4$ + FiB4 x 0.19 - (micro RNA $122 \times 0.086$ + micro RNA $855 \times$} $\mathbf{0 . 0 5 2}+$ bilirubin $\times \mathbf{0 . 4 4}$ ), where 4.558 is considered a numeric constant. Levels of CUFI in significant liver fibrosis and advanced liver fibrosis were presented in figure 1C. The AUC of the score was assessed for identifying significant fibrosis showing an AUC of 0.85 (figure $2 \mathrm{~A}$ ). A cut-off level of 0.44 presented sensitivity of $77 \%$, specificity of $79 \%$, PPV of $68 \%$, NPV of $86 \%$, and overall accuracy of $78 \%$ for identification of significant liver fibrosis (Table 3). Our predictive score at a cut-off value of 0.44 yielded an AUC of 0.81 for predicting advanced fibrosis (figure 2B). It showed $80 \%$ sensitivity, $66 \%$ specificity, $35 \%$ positive predictive value, $95 \%$ negative predictive value, and overall accuracy of $68 \%$ for identification of advanced liver fibrosis (Table 4).

\section{Discussion}

Liver disease is a considerable cause of mortality and morbidity $[5,28]$. Accurate determination of the disease stage is mandatory for clinical decision-making. Still, liver histopathology is considered the golden benchmark for the diagnosis of liver fibrosis [29]. However, the invasiveness of biopsy, the potential associated complications, and poor sample quality urge the search for noninvasive diagnostic markers for liver fibrosis [30]. The need to find predictors of the hepatic fibrosis stage at the molecular level is increasing as hepatic fibrosis progression may result in hepatocellular carcinoma development $[31,32]$. The miRNAs are now considered to be important indicators of liver fibrosis [33], and liver carcinogenesis [32]. In the current study, we analyzed the performance of microRNAs as hepatic fibrosis biomarkers. Patients suffering significant and advanced fibrosis showed a significantly lower value of MiR-122. Our study showed more decrease in serum miR-122 in patients with advanced hepatic fibrosis $(F 3,4)$ when compared with significant fibrosis (F2-4) which agreed with Trebicka et al who stated that loss of functional hepatocytes in the late stages of fibrosis (F3-4) might cause decreased serum levels of miRNA-122 [34]. Moreover, the suppressive function of miR-122 that hinders the proliferation of hepatic stellate cells and fibrogenesis is absent in the late stages of fibrosis. [35]. Also, many studies proved an inverse relationship between miR-122 and the stage of fibrosis in HCV-based liver disease [36, 37]. Furthermore, we formulated a novel score (CUFI) which shows a greater diagnostic value for pointing to significant and advanced hepatic fibrosis taking histopathology as the gold standard ( AUR 0.85, 0.81 respectively). The score included microRNA 122, microRNA 855, FIB4, and bilirubin. It is well known that changes in miRNA-122 serum levels occur early in liver disease, suggesting that miRNA -122 can be a reliable predictor of hepatic injury [33]. Additionally, miR-122 induces HCV translation and stimulates viral genomic RNA replication [38]. Also, it is inversely correlated with fibrosis in HCV-infected patients [36, 37]. miR-122 levels were higher levels in the non-significant liver followed by reduced levels in significant liver fibrosis in response to inflammation and damage of liver cells confirming previous studies. miR885 was found to correlate with different liver pathologies [39-41]. Bilirubin is the lipophilic end product of heme breakdown [42]. Hyperbilirubinemia is common in chronic liver disease and serum bilirubin is 
routinely included in the biochemical assessment of such patients, Serial measurement of serum bilirubin is might be indicative of liver disease progression being an indirect marker of hepatic fibrosis [43].

Our novel score CUFI which is composed of serum bilirubin, miRNA -122, and miRNA-855 performed even better than common liver fibrosis scores. Its AUC was 0.85 for documenting significant liver fibrosis and 0.81 for detection of advanced fibrosis which was the greatest score among common liver fibrosis scores. This could be cleared up by the fact that most of the common liver fibrosis scores depend on multiple biochemical and serum parameters which may differ with many factors such as blood sampling time, the blood sample delivery time, and liver functional status [44]. On the other hand,miRNAs are stably present in the blood, making them suitable as biomarkers [45]. The limitation of our study included a small sample, so our results should be validated on larger samples.

In conclusion, Cairo University Fibrosis Index is more accurate than the existing fibrosis scores as it gives more indicative results for judging fibrosis.

\section{Abbreviations}

AAR: AST/ALT ratio; ALT: alanine aminotransferase; APRI: aspartate to platelet ratio index; AST: aspartate aminotransferase; AUC: area under curve; BRC: Biotechnology Research Center; $\mathrm{CHC}$ : Chronic hepatitis C;CUFI: Cairo university fibrosis index; DAAs : direct-acting antivirals; Fl: Fibrosis index; FIB-4: Fibrosis-4; GUCl: Gotebörg University Cirrhosis Index; HBV: hepatitis B virus; HCV: Hepatitis C virus; HCV: Hepatitis C virus; MDA: multivariate discriminant analysis; Mi: micro; PCR: Polymerase chain; RNA: ribonucleic acid; ROC: receiver operating characteristics; RT-PCR: reverse transcriptase-polymerase chain reaction

\section{Declarations}

\section{Acknowledgements}

Not applicable.

\section{Authors' contributions}

$A H, O D, Z A, O M$ and EA designed the study. ZA measured the micro RNA. AM and EA collected the clinical data and the samples. OAM and OM analyse the data. AM shared in writing the manuscript. OM and OD wrote the manuscript. All authors revised and approved the manuscript.

\section{Funding}

Not applicable.

\section{Availability of data and materials}


Data not available due to [ethical/legal] restrictions: Due to research nature, the study participants did not agree for their data to be shared publicly, so supporting data is not available. The datasets used and/or analyzed during the current study are available from the corresponding author on reasonable request.

\section{Ethics approval and consent to participate}

The present study was organized in accordance with the Declaration of Helsinki 1973 and Good Clinical Practice guidelines. The Ethics Committee of Endemic Medicine and the Hepato-gastroenterology Department reviewed and approved the protocol. Every patient signed informed consent before taking part in the study

\section{Consent for publication}

Not applicable.

\section{Competing interests}

The authors have no competing interests to declare.

\section{References}

1. Bataller R, Brenner DA. Liver fibrosis. J Clin Invest. 2005; 115(2):209-218. 3. Tsukada S, Parsons CJ, Rippe RA. Mechanisms of liver fibrosis. Clin ChimActa. 2006; 364(1-2):33-60.

2. Carmona I, Cordero P, Ampuero J, Rojas A, Romero-Gómez M. Role of assessing liver fibrosis on management of chronic hepatitis C virus infection. Clin Microbiol Infect. 2016; 22(10):839-45.

3. El Kassas M, Omran D, Elsaeed K, Alboraie M, Elakel W, El Tahan A, Abd El Latif Y, Nabeel MM, Korany M, Ezzat S, El-Serafy M, ElShazly Y, Doss W, Esmat G. Spur-of-the-Moment Modification in National Treatment Policies Leads to a Surprising HCV Viral Suppression in All Treated Patients: Real-Life Egyptian Experience.. J Interferon Cytokine Res. 2018;38(2):81-5.

4. Bunchorntavakul C, Reddy KR. Management of hepatitis $C$ before and after liver transplantation in the era of rapidly evolving therapeutic advances. J Clin TranslHepatol. 2014;2(2):124-133

5. Zayed RA, Omran D, Zayed AA, Elmessery LO. Determinants of Infection Outcome in HCV-Genotype 4.. Viral Immunol. 2017;30(8):560-67.

6. El Kassas M, Alboraie M, Omran D, Salaheldin M, Wifi MN, ElBadry M, El Tahan A, Ezzat S, Moaz E, Farid AM, Omar H, Abouelkhair M, Afify S, Elsaeed K, Shazly Y, Doss W, Esmat G. An account of the real-life hepatitis $\mathrm{C}$ management in a single specialized viral hepatitis treatment centre in Egypt: results of treating 7042 patients with 7 different direct acting antiviral regimens. Expert Rev GastroenterolHepatol. 2018 24:1-8.

7. Mendes LC, Stucchi RS, Vigani AG. Diagnosis and staging of fibrosis in patients with chronic hepatitis C: comparison and critical overview of current strategies. Hepat Med. 2018 3; 10:13-22. 
8. Mobarak L, Nabeel MM, Hassan E, Omran D, Zakaria Z Real-time elastography as a noninvasive assessment of liver fibrosis in chronic hepatitis $C$ Egyptian patients: a prospective study. Ann Gastroenterol. 2016;29(3):358-62.

9. Zayed RA, Omran D, Mokhtar DA, Zakaria Z, Ezzat S, Soliman MA, Mobarak L, ElSweesy H, Emam G. Association of Toll-Like Receptor 3 and Toll-Like Receptor 9 Single Nucleotide Polymorphisms with Hepatitis C Virus Infection and Hepatic Fibrosis in Egyptian Patients. Am J Trop Med Hyg. 2017; 96(3):720-26.

10. Omran D, Yosry A, Darweesh SK, Nabeel MM, El-Beshlawey M, Saif S, Fared A, Hassany M, Zayed RA. Enhanced liver fibrosis test using ELISA assay accurately discriminates advanced stage of liver fibrosis as determined by transient elastographyfibroscan in treatment naïve chronic HCV patients. Clin Exp Med. 2018;18(1):45-50.

11. Omran D, Zayed RA, Nabeel MM, Mobarak L, Zakaria Z, Farid A, Hassany M, Saif S, Mostafa M, Saad OK, Yosry A. Evaluating Diagnostic Accuracy of Noninvasive Tests in Assessment of Significant Liver Fibrosis in Chronic Hepatitis C Egyptian Patients. Viral Immunol. 2018; 31(4): 315-20.

12. Attallah AM, Omran D, Omran MM, Abdelrazek MA, Zayed R, Essawey RE, Saif S, Farid A, Hassany M, Yosry A, Omar A. Extracellular Matrix Proteins Substantiate IL-28B T allele Effect on Histological Outcome of Chronic Hepatitis C. Ann Hepatol. 2018;17(4):569-76.

13. Attallah AM, Albannan MS, Omran MM, Zayed R, Saif S, Farid A, Hassany M, Yosry A, Omran D. A panel of a mitogenic (PDGF), biochemical (albumin) and demographic (age) parameters for the noninvasive assessment of hepatic fibrosis. Br J Biomed Sci. 2019;76(3):105-10.

14. Attallah AM, El-Far M, Omran MM, Farid K, Albannan MS, El-Dosoky I. Noninvasive diagnosis of liver fibrosis and cirrhosis in chronic hepatitis C patients. J Clin Lab Anal. 2013;27(2):121-29.

15. Ha M, Kim VN. Regulation of microRNA biogenesis. Nat Rev Mol Cell Biol. 2014;15(8):509-24.

16. El-Ahwany E, Nagy F, Zoheiry M, Shemis M, Nosseir M, Taleb HA, El Ghannam M, Atta R, Zada S. Circulating miRNAs as Predictor Markers for Activation of Hepatic Stellate Cells and Progression of HCV-Induced Liver Fibrosis. Electron Physician. 2016;8(1):1804-10.

17. Li G, Cai G, Li D, Yin W. MicroRNAs and liver disease: viral hepatitis, liver fibrosis and hepatocellular carcinoma. Postgrad Med J.2014; 90(1(1060):106-12.

18. Bedossa P, Poynard T and the French METAVIR Cooperative Study Group. An algorithm for grading activity in chronic hepatitis C. Hepatol 1996; 24:289-93.

19. Ohta T, Sakaguchi K, Fujiwara A, Fujioka S, Iwasaki Y, Makino Y, Araki Y, Shiratori Y. Simple surrogate index of the fibrosis stage in chronic hepatitis $C$ patients using platelet count and serum albumin level. Actamedica Okayama. 2006;60:77-84.

20. Omran MM, Farid K, Emran TM, Attallah AA. Fibro-a score as a simple and useful non-invasive test for predicting significant liver fibrosis in chronic hepatitis C patients. Arab J Gastroenterol. 2011;12(2):74-9.

21. Hui AY, Chan HL-Y, Wong VW-S, Liew C-T, Chim AM-L, Chan FK-L, Sung JJ-Y. Identification of Chronic Hepatitis B Patients without Significant Liver Fibrosis by a Simple Noninvasive Predictive Model. Am 
J Gastroenterol. 2005; 100(3):616-23.

22. Sheth SG, Flamm SL, Gordon FD, Chopra S. AST/ALT ratio predicts cirrhosis in patients with chronic hepatitis C virus infection. Am J Gastroenterol. 1998;93(1):44-8.

23. Attallah AM, El-Far M, Omran MM, Farid K, Albannan MS, El-Dosoky I. Noninvasive diagnosis of liver fibrosis and cirrhosis in chronic hepatitis C patients. J Clin Lab Anal. 2013;27(2):121-9.

24. Wai CT, Greenson JK, Fontana RJ, Kalbfleisch JD, Marrero JA, Conjeevaram HS, Lok AS. A simple noninvasive index can predict both significant fibrosis and cirrhosis in patients with chronic hepatitis C. Hepatol 2003; 38:518-26.

25. Hsieh YY, Tung SY, Lee IL, Lee K, Shen CH, Wei KL, Chang TS, Chuang CS, Wu CS, Lin YH. FibroQ: an easy and useful noninvasive test for predicting liver fibrosis in patients with chronic viral hepatitis. Chang Gung Med J. 2009;32(6):614-22.

26. Islam S, Antonsson L, Westin J, Lagging M. Cirrhosis in hepatitis C virus-infected patients can be excluded using an index of standard biochemical serum markers. Scand J Gastroenterol. 2005;40(7):867-72.

27. Sterling RK, Lissen E, Clumeck N, Sola R, Correa MC, Montaner J, S Sulkowski M, Torriani FJ, Dieterich DT, Thomas DL, Messinger D, Nelson M; APRICOT Clinical Investigators. Development of a simple noninvasive index to predict significant fibrosis in patients with HIV/HCV coinfection. Hepatol 2006;43(6):1317-25.

28. Monga HK, Rodriguez-Barradas MC, Breaux K, Khattak K, Troisi CL, Velez M, Yoffe B. Hepatitis C virus infection-related morbidity and mortality among patients with human immunodeficiency virus infection. Clin Infect Dis. 2001;33(2):240-7.

29. Bedossa P, Dargere D, Paradis V. Sampling variability of liver fibrosis in chronic hepatitis C. Hepatol $2003 ; 38,1449-57$.

30. Pinzani M, Rombouts K, Colagrande S. Fibrosis in chronic liver disease: diagnostic and management. J. Hepatol.2005; 42, 12-36.

31. Mobarak L, Omran D, Nabeel MM, Zakaria Z. Fibro markers for prediction of hepatocellular carcinoma in Egyptian patients with chronic liver disease. J Med Virol. 2017;89(6):1062-68.

32. Gramantieri L, Fornari F, Callegari E, Sabbioni S, Lanza G, Croce CM, Bolondi L, Negrini M. MicroRNA involvement in hepatocellular carcinoma. J Cell Mol Med. 2008;12:2189-204.

33. He Y, Huang C, Zhang SP, Sun X, Long XR, Li J. The potential of microRNAs in liver fibrosis. Cell Signal. 2012;24:2268-72.

34. Trebicka J, Anadol E, Elfimova N, Strack I, Roggendorf M, Viazov S, Wedemeyer I, Drebber U, Rockstroh J, Sauerbruch T, Dienes HP, Odenthal M. Hepatic and serum levels of miR-122 after chronic HCV-induced fibrosis. J Hepatol. 2013; 58(2):234-9.

35. Li J, Ghazwani M, Zhang Y, Lu J, Li J, Fan J, Gandhi CR, Li S. miR-122 regulates collagen production via targeting hepatic stellate cells and suppressing P4HA1 expression. J Hepatol. 2013;58:522-28. 
36. Marquez RT, Bandyopadhyay S, Wendlandt EB, Keck K, Hoffer BA, Icardi MS, Christensen RN, Schmidt WN, McCaffrey AP. Correlation between microRNA expression levels and clinical parameters associated with chronic hepatitis C viral infection in humans. Lab Invest. 2010;90:1727-36.

37. Morita K, Taketomi A, Shirabe K, Umeda K, Kayashima H, Ninomiya M, Uchiyama H, Soejima Y, Maehara Y. Clinical significance and potential of hepatic microRNA-122 expression in hepatitis C. Liver Int. 2011;31:474-84

38. Kunden RD, Khan JQ, Ghezelbash S, Wilson JA. The Role of the Liver-Specific microRNA, miRNA-122 in the HCV Replication Cycle. Int J Mol Sci. 2020 ;21(16):5677.

39. Gui J, Tian Y, Wen X, Zhang W, Zhang P, Gao J, Run W, Tian L, Jia X, Gao Y. Serum microRNA characterization identifies miR-885-5p as a potential marker for detecting liver pathologies. Clin Sci (Lond). 2011;120(5):183-93.

40. Cabral BCA, Hoffmann L, Bottaro T, Costa PF, Ramos ALA, Coelho HSM, Villela-Nogueira CA, Ürményi TP, Faffe DS, Silva R. Circulating microRNAs associated with liver fibrosis in chronic hepatitis C patients. BiochemBiophys Rep. 2020;24:100814.

41. Zekri AN, Youssef AS, El-Desouky ED, Ahmed OS, Lotfy MM, Nassar AA, Bahnassey AA. Serum microRNA panels as potential biomarkers for early detection of hepatocellular carcinoma on top of HCV infection. Tumour Biol. 2016;37(9):12273-86.

42. Vítek L, Ostrow JD. Bilirubin chemistry and metabolism; harmful and protective aspects. Curr Pharm Des. 2009;15(25):2869-83.

43. Paul YK, Stanley MC, Joseph KL. ACG Practice Guideline: evalution of abnormal liver chemistries. AmJ Gastroenterol 2016; 112(1), 18-35.

44. Ouyang GX, Zhang YM, Zhu SL, Wang P, Ren Y, Li JH, Liu YK, Chen J, Xiang BD, Li LQ, Liu JY, Zhang ZM. A novel, non-invasive model for diagnosing liver fibrosis stage in patients with hepatocellular carcinoma. Sci Rep. 2018 30;8(1):13074.

45. Tadokoro T, Morishita A, Masaki T. Diagnosis and therapeutic management of liver fibrosis by MicroRNA. Int J Mol Sci. 2021;22(15):8139.

\section{Tables}

Table 1.Calculation of noninvasive hepatic fibrosis indexes 


\begin{tabular}{|c|c|c|}
\hline indexes & Calculations & References \\
\hline $\mathrm{Fi}$ & 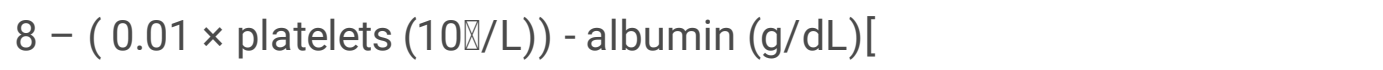 & [19] \\
\hline $\begin{array}{l}\text { Fibro- } \\
\text { Alfa }\end{array}$ & $\begin{array}{l}1.35+\mathrm{AFP}(\mathrm{IU} / \mathrm{ml}) \times 0.009584+\mathrm{AAR}(\mathrm{AST} / \mathrm{ALT}) \times 0.243 \text { - platelet count } \\
(109 / \mathrm{l}) \times 0.001624\end{array}$ & [20] \\
\hline $\begin{array}{l}\text { Hui } \\
\text { index }\end{array}$ & $3.148+0.167 \times \mathrm{BMI}+0.088 \times$ bilirubin $-0.151 \times$ albumin $-0.019 \times$ platelet & [21] \\
\hline AAR & - $\quad$ AST/ALT & [22] \\
\hline $\begin{array}{l}\text { BRC } \\
\text { score }\end{array}$ & $\begin{array}{l}1.02+0.4 \times \text { AFP }(U / I)+0.19 \times \text { Age (years) }-0.02 \times \text { Platelet count } \\
\left(10^{9} / \mathrm{l}\right)\end{array}$ & [23] \\
\hline APRI & - $\quad$ AST(IU/L )/upper limit of normal/platelet count $\left(10^{9} / \mathrm{L}\right) \times 100$ & [24] \\
\hline Fibro-Q & {$[(10 \times$ age $($ years $) \times$ AST $\times$ PT INR $) /(P L T \times A L T)]$.} & [25] \\
\hline GUCl & - $\quad$ AST $\times$ INR $\times 100 /$ Platelet count $\left(10^{9} / L\right)$ & [26] \\
\hline FIB-4 & - $\quad[$ Age $[y r s.] \times A S T[U / L] /($ platelet count $[109 / L] \times(A L T[U / L] 1 / 2)]$ & [27] \\
\hline
\end{tabular}

Table 2. Comparison between non-significant hepatic fibrosis (F0-F1) and those with significant (F2 - F4) and advanced hepatic fibrosis (F3-F4). 


\begin{tabular}{|c|c|c|c|c|c|c|}
\hline $\begin{array}{l}P \\
\text { value }\end{array}$ & $\begin{array}{l}\text { Advanced } \\
\text { fibrosis } \\
(n=12)\end{array}$ & $\begin{array}{l}\text { Non advanced } \\
\text { fibrosis } \\
(n=58)\end{array}$ & $\begin{array}{l}P \\
\text { value }\end{array}$ & $\begin{array}{l}\text { Significant } \\
\text { fibrosis } \\
(n=26)\end{array}$ & $\begin{array}{l}\text { Non significant } \\
\text { fibrosis } \\
(n=44)\end{array}$ & Variable \\
\hline 0.015 & $46.3 \pm 5.5$ & $39.9 \pm 8.6$ & 0.004 & $44.7 \pm 5.54$ & $38.8 \pm 9.2$ & Age (years) \\
\hline 0.39 & $\begin{array}{l}42.08 \pm \\
14.5\end{array}$ & $38.6 \pm 12.4$ & 0.7 & $40.0 \pm 13.85$ & $38.8 \pm 12.1$ & $\operatorname{ALT}(\mathrm{U} / \mathrm{L})$ \\
\hline 0.13 & $\begin{array}{l}42.83 \pm \\
11.8\end{array}$ & $37.6 \pm 10.3$ & 0.06 & $41.6 \pm 10.11$ & $36.7 \pm 10.7$ & AST(U/L) \\
\hline 0.03 & $0.91 \pm 0.25$ & $0.76 \pm 0.20$ & 0.001 & $0.9 \pm 0.21$ & $0.78 \pm 0.1$ & $\begin{array}{l}\text { Bilirubin } \\
\text { (mg/dl) }\end{array}$ \\
\hline 0.33 & $\begin{array}{l}43.50 \pm \\
3.87\end{array}$ & $42.49 \pm 3.4$ & 0.54 & $42.9 \pm 3.85$ & $42.3 \pm 3.3$ & $\begin{array}{l}\text { Albumin } \\
(\mathrm{g} / \mathrm{L})\end{array}$ \\
\hline 0.85 & $\begin{array}{l}13.73 \pm \\
1.04\end{array}$ & $13.76 \pm 1.4$ & 0.62 & $13.8 \pm 1.27$ & $13.6 \pm 1.3$ & $\mathrm{Hb}(\mathrm{g} / \mathrm{dl})$ \\
\hline 0.68 & $\begin{array}{l}288.6 \pm \\
94.4\end{array}$ & $278.1 \pm 78.1$ & 0.96 & $\begin{array}{l}280.5 \pm \\
89.5\end{array}$ & $279.5 \pm 75.7$ & $\begin{array}{l}\text { PLT } \\
\left(\times 10^{9} / \mathrm{L}\right)\end{array}$ \\
\hline 0.91 & $86.3 \pm 6.9$ & $86.6 \pm 6.8$ & 0.61 & $86.0 \pm 6.11$ & $86.8 \pm 7.3$ & PC (\%) \\
\hline 0.89 & $1.14 \pm .07$ & $1.14 \pm 0.01$ & 0.74 & $1.14 \pm 0.07$ & $1.1 \pm 0.08$ & INR \\
\hline 0.99 & $92.4 \pm 13.7$ & $92.4 \pm 13.4$ & 0.88 & $92.1 \pm 13.61$ & $92.6 \pm 13.4$ & $\begin{array}{l}\text { Glucose } \\
(\mathrm{mg} / \mathrm{dl})\end{array}$ \\
\hline 0.29 & $59,6 \pm 99,6$ & $105,7 \pm 143,9$ & 0.87 & $94,3 \pm 138,0$ & $99,8 \pm 139$ & $\begin{array}{l}\text { PCR (IU ml } \\
\left.\mathrm{X} 10^{4}\right)\end{array}$ \\
\hline 0.50 & $6.2 \pm 3.7$ & $5.5 \pm 3.2$ & 0.75 & $5.8 \pm 3.5$ & $5.5 \pm 3.13$ & AFP (U/L) \\
\hline 0.007 & $26.9 \pm 1.8$ & $29.1 \pm 2.6$ & $\begin{array}{l}<.0001 \\
0.000\end{array}$ & $27.1 \pm 2.3$ & $29.6 \pm 2.33$ & $\begin{array}{l}\text { Micro RNA } \\
122\end{array}$ \\
\hline 0.72 & $26.9 \pm 1.9$ & $27.2 \pm 1.7$ & 0.51 & $27.3 \pm 1.7$ & $27.03 \pm 1.73$ & $\begin{array}{l}\text { Micro RNA } \\
192\end{array}$ \\
\hline 0.04 & $25.1 \pm 1.1$ & $26.3 \pm 1.9$ & 0.01 & $25.3 \pm 1.5$ & $26.5 \pm 1.99$ & $\begin{array}{l}\text { Micro RNA } \\
855\end{array}$ \\
\hline 0.75 & $29.6 \pm 3.8$ & $29.9 \pm 3.6$ & 0.52 & $30.3 \pm 3.3$ & $29.7 \pm 3.81$ & $\begin{array}{l}\text { Micro RNA } \\
375\end{array}$ \\
\hline 0.66 & $31.7 \pm 3.9$ & $31.3 \pm 3.1$ & 0.18 & $30.6 \pm 3.4$ & $31.7 \pm 3.07$ & $\begin{array}{l}\text { Micro RNA } \\
224\end{array}$ \\
\hline 0.33 & $32.8 \pm 3.4$ & $34.4 \pm 5.6$ & 0.78 & $33.9 \pm 3.4$ & $34.3 \pm 5.96$ & $\begin{array}{l}\text { Micro RNA } \\
221\end{array}$ \\
\hline
\end{tabular}


Table 3.Comparison of our predictive score and common liver fibrosis scores for predicting significant and advanced fibrosis

\begin{tabular}{|c|c|c|c|c|c|c|c|c|}
\hline AUC & $\begin{array}{l}P \\
\text { value }\end{array}$ & $\begin{array}{l}\text { Advanced } \\
\text { fibrosis } \\
(n=12)\end{array}$ & $\begin{array}{l}\text { Non } \\
\text { advanced } \\
\text { fibrosis } \\
(n=58)\end{array}$ & AUC & $\begin{array}{l}\mathrm{P} \\
\text { value }\end{array}$ & $\begin{array}{l}\text { Significant } \\
\text { fibrosis } \\
(n=26)\end{array}$ & $\begin{array}{l}\text { Non- } \\
\text { significant } \\
\text { fibrosis } \\
(n=44)\end{array}$ & Variable \\
\hline 0.399 & 0.295 & $\begin{array}{l}-38.39 \pm \\
4.03\end{array}$ & $\begin{array}{l}-37.18 \pm \\
3.53\end{array}$ & 0.46 & 0.545 & $\begin{array}{l}-37.73 \\
\pm 3.93\end{array}$ & $\begin{array}{l}-37.18 \pm \\
3.45\end{array}$ & $\mathrm{FI}$ \\
\hline 0.485 & 0.937 & $\begin{array}{l}1.19 \pm \\
0.17\end{array}$ & $1.20 \pm 0.16$ & 0.53 & 0.434 & $\begin{array}{l}1.22 \\
\pm 0.19\end{array}$ & $1.19 \pm 0.14$ & $\begin{array}{l}\text { Fibro- } \\
\text { Alfa }\end{array}$ \\
\hline 0.561 & 0.740 & $\begin{array}{l}-3.86 \pm \\
2.29\end{array}$ & $-4.06 \pm 1.81$ & 0.54 & 0.956 & $\begin{array}{l}-3.89 \\
\pm 2.17\end{array}$ & $\begin{array}{l}-4.10 \pm \\
0.26\end{array}$ & $\begin{array}{l}\text { Hui } \\
\text { score }\end{array}$ \\
\hline 0.569 & 0.812 & $\begin{array}{l}1.07 \pm \\
0.27\end{array}$ & $1.04 \pm 0.37$ & 0.60 & 0.151 & $\begin{array}{l}1.12 \pm \\
0.38\end{array}$ & $0.99 \pm 0.33$ & AAR \\
\hline 0.579 & 0.500 & $\begin{array}{l}17.99 \pm \\
5.76\end{array}$ & $\begin{array}{l}16.61 \pm \\
6.55\end{array}$ & 0.61 & 0.082 & $\begin{array}{l}6.23 \pm \\
2.99\end{array}$ & $5.0 \pm 2.67$ & BRC \\
\hline 0.580 & 0.546 & $\begin{array}{l}0.39 \pm \\
0.12\end{array}$ & $0.37 \pm 0.15$ & 0.62 & 0.180 & $\begin{array}{l}0.40 \\
\pm 0.13\end{array}$ & $0.35 \pm 0.15$ & APRI \\
\hline 0.583 & 0.308 & $\begin{array}{l}2.25 \pm \\
1.47\end{array}$ & $1.87 \pm 1.11$ & 0.62 & 0.018 & $\begin{array}{l}2.37 \pm \\
1.53\end{array}$ & $1.68 \pm 0.83$ & Fibro -Q \\
\hline 0.602 & 0.151 & $\begin{array}{l}6.54 \pm \\
3.39\end{array}$ & $5.24 \pm 2.69$ & 0.62 & 0.159 & $\begin{array}{l}18.25 \pm \\
5.99\end{array}$ & $\begin{array}{l}16.01 \pm \\
6.56\end{array}$ & $\mathrm{GUCl}$ \\
\hline 0.632 & 0.02 & $1.2 \pm 0.1$ & $0.98 \pm 0.31$ & 0.67 & 0.001 & $\begin{array}{l}1.21 \pm \\
0.21\end{array}$ & $0.90 \pm 0.44$ & FIB -4 \\
\hline
\end{tabular}

Table 4. Diagnostic power of single and combined candidate biomarkers 


\begin{tabular}{|c|c|c|c|c|c|c|c|}
\hline Markers & AUC $(95 \% \mathrm{Cl})$ & $\begin{array}{l}\text { Cut- } \\
\text { off }\end{array}$ & Sen & Spe & PPV & NPV & Accuracy \\
\hline \multicolumn{8}{|c|}{ Significant vs non-significant } \\
\hline Micro RNA 855 & $\begin{array}{l}0.64(0.51- \\
0.78)\end{array}$ & 26 & 46 & 57 & 38 & 65 & 53 \\
\hline Bilirubin & $\begin{array}{l}0.66(0.51- \\
0.81)\end{array}$ & 0.75 & 65 & 65 & 51 & 75 & 64 \\
\hline FIB-4 & $\begin{array}{l}0.67(0.53- \\
0.81)\end{array}$ & 0.95 & 64 & 65 & 52 & 76 & 65 \\
\hline Micro RNA 122 & $\begin{array}{l}0.79(0.86- \\
0.91)\end{array}$ & 26 & 72 & 76 & 64 & 83 & 75 \\
\hline $\begin{array}{l}\text { Cairo University Fibrosis } \\
\text { Index }\end{array}$ & $\begin{array}{l}0.85(0.75- \\
0.95)\end{array}$ & 0.44 & 77 & 79 & 68 & 86 & 78 \\
\hline \multicolumn{8}{|l|}{ Advanced vs non-advanced } \\
\hline Micro RNA 855 & $\begin{array}{l}0.62(0.48- \\
0.77)\end{array}$ & 26 & 50 & 58 & 20 & 85 & 56 \\
\hline Bilirubin & $\begin{array}{l}0.65(0.44- \\
0.86)\end{array}$ & 0.75 & 52 & 59 & 21 & 86 & 57 \\
\hline FIB -4 & $\begin{array}{l}0.68(0.53- \\
0.83)\end{array}$ & 0.95 & 70 & 60 & 26 & 90 & 62 \\
\hline Micro RNA 122 & $\begin{array}{l}0.79(0.65- \\
0.93)\end{array}$ & 26 & 80 & 66 & 32 & 94 & 68 \\
\hline $\begin{array}{l}\text { Cairo University Fibrosis } \\
\text { Index }\end{array}$ & $\begin{array}{l}0.81(0.69- \\
0.93)\end{array}$ & 0.44 & 80 & 66 & 35 & 95 & 68 \\
\hline
\end{tabular}

\section{Figures}



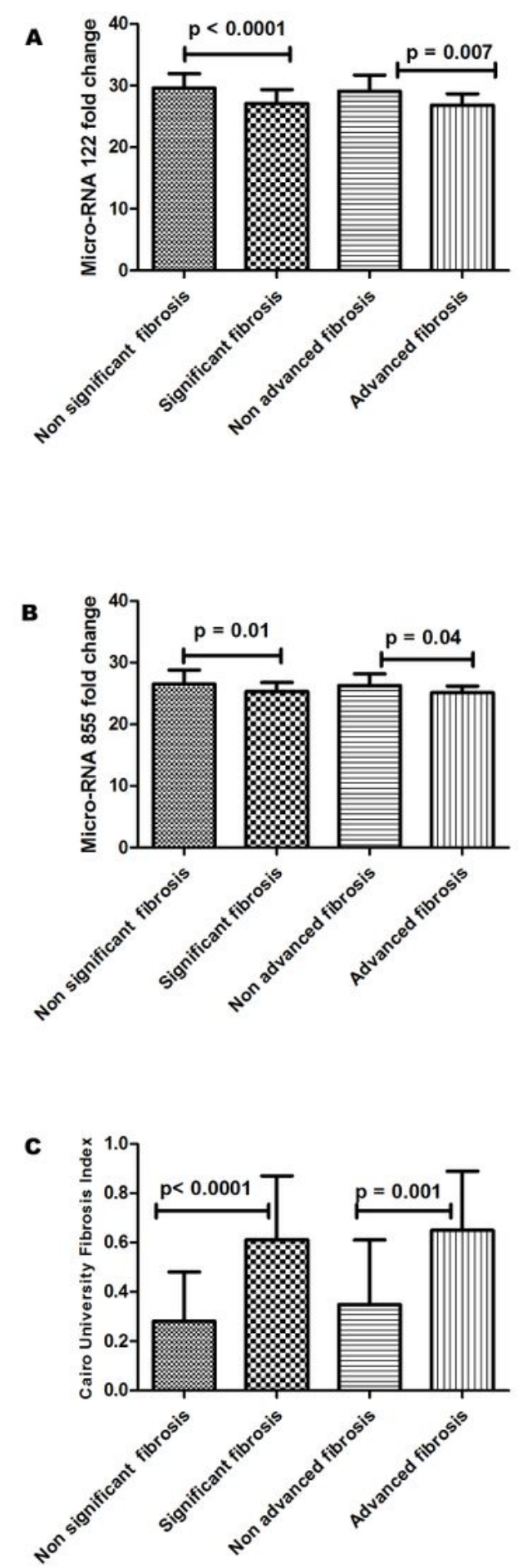

Figure 1

Levels of candidate markers and Cairo Univeristy Fibrosis Index. A. Level of miro-RNA 122. B. Level of miro-RNA 855. C. Level of Cairo University Fibrosis Index. 

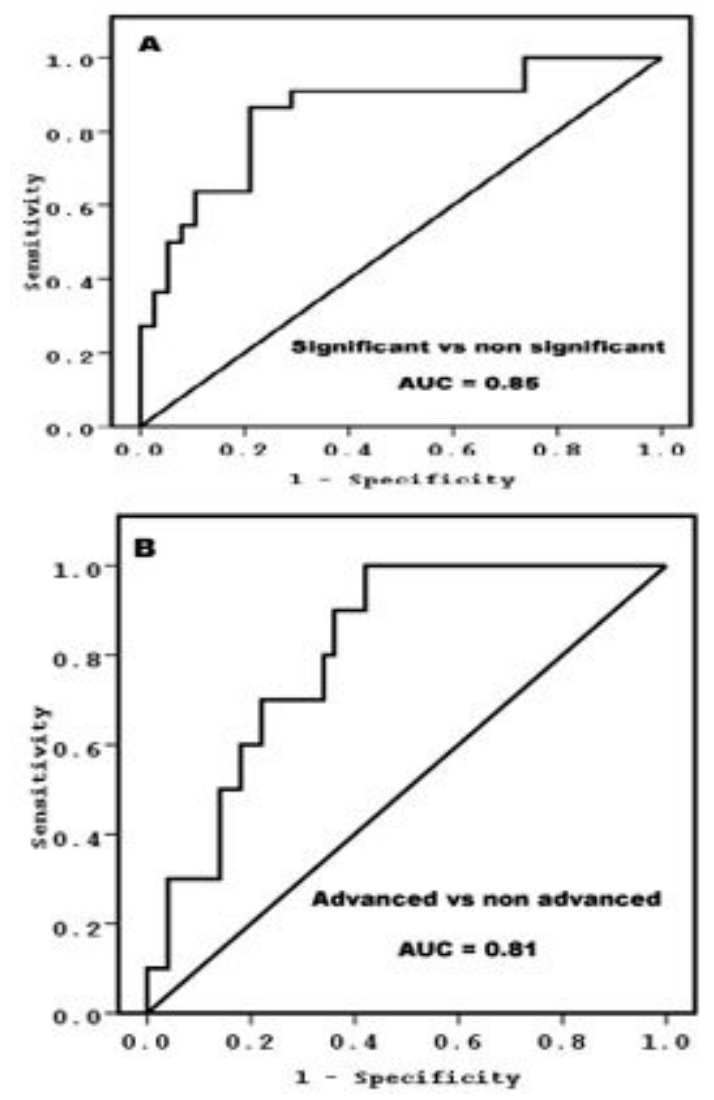

Figure 2

ROC curves of Cairo Univeristy Fibrosis Index for identifying. A. Significant fibrosis B. Advanced fibrosis. 